\title{
Inter-functional Market Orientation Between Marketing Departments and Technical Departments in the Management of the New Product Development Process
}

\author{
George Gresham \\ Texas A\&M University-Kingsville \\ John Hafer \\ University of Nebraska at Omaha \\ Edward Markowski \\ Old Dominion University
}

\begin{abstract}
The marketing concept states that firms who first determine and then satisfy customer needs should realize superior performance. Market orientation (MO) operationalizes the marketing concept and is the organization-wide generation of market intelligence, dissemination of the intelligence across departments, and organization-wide responsiveness to it (Kohli and Jaworski, 1990). Market oriented firms should enjoy successful new product programs (Slater and Narver, 1994). However, empirical findings are mixed. This research conceptualizes $\mathrm{MO}$ at the departmental level, specifically within cross-functional new product teams. Findings here suggest interfunctional market orientation (IFMO), between marketing and technology groups, is directly related to new product program success.
\end{abstract}

\section{Introduction}

The importance of new product success is evidenced by its reported impact on firm performance and its strategic role as a benchmark metric for driving growth and sustaining long-term competitive advantage. For example, before JVC pioneered the VHS format and launched the home VCR market, it was virtually unknown outside of Japan. Upstart Apple outpaced competitive stalwarts General Electric, AT\&T and Honeywell to challenge IBM's dominant position with an outpouring of successful new products that made it a major player in the U.S. personal computer industry. Nokia, previously a Finnish boot manufacturer, rode from obscurity to household name on its innovative cell phone technology. A small British pharmaceutical house named Glaxo catapulted to No. 2 in the new product-driven pharmaceutical industry, not by mergers and acquisitions or other conglomerating activities, but with the introduction of a single, new anti-ulcer drug, Zantac ${ }^{\mathrm{TM}}$.

Just the promise of new product success can boost a firm's investment value. For example, on May 22, 2003, Genetech's stock rose $40 \%$ with announcement of favorable clinical trials for its new anti-cancer drug. Conversely, reports of failure or delayed product approval can be devastating. When a Food and Drug Administration advisory 
panel failed to endorse Maxim Pharmaceutical's new liver cancer drug, the hopeful San Diego, Calif., biotechnology firm suffered a stock decline of $44 \%$ in one day.

Yet, despite its importance to growth and long-term survival for many firms, new product success remains frustratingly elusive. Crawford (1977) and Ottum and Moore (1997) claim new product success rates have not improved in $25+$ years. In a study by Data, Monitor, Inc., $80 \%$ of newly introduced products fail to establish market presence after two years (Marketing, July 12, 1996). New product failure is not limited to a few industries with manufactured products; services suffer failure rates estimated at $80 \%$ (Clancy and Shulman, 1991). News magazines and industry trade journals have documented ubiquitous new product failures. For example, according to a Wall Street Journal article on June 11, 2003, p. A12, drug makers rolled out just 17 novel drugs in 2002, the worst new-product performance since 1983. Also, according to a Frozen Food Digest article in May 17, p. 76, an estimated 1,935 products from 20 food companies had a failure rate of $70 \%$ to $80 \%$.

\section{Purpose}

The purpose of this research is to investigate whether market orientation, as defined by the independent variable inter-functional market orientation (IFMO), is significantly related to new product program success as opposed to the customary approach of measuring the success of a single product or, success of the firm in total. This research adds to the new product development (NPD) literature in several unique ways.

First, this research introduces the calculation of the independent variable IFMO. IFMO, as defined here, is an inter-functional measure of market orientation attainable by independently measuring the level of market orientation of both the marketing group members and technology group members. Both the marketing departments and the technology departments are responsible for creating new products and each has a stake in the success or failure of those new products. As a managerial tenet, it would be logical to assume that the greater these two groups work together toward satisfying the market's needs, the greater the new product program's chances of success would be. But, while apparently logical as this might seem, does empirical evidence support the presumed logic? If these two departments are not "on the same page", the management issue is, does it matter? Is there a link between "being on the same page" and the success of the new product programs the company creates? If the evidence supports a positive relationship between this inter-functional market orientation (IFMO) and program success, it becomes a managerial mandate to assure that these two very different departments are working toward the same goal and with the same vision.

Second, previous research (e.g., Matsuno et al., 2002) has approached market orientation based on the responses from one person in a firm. No previous attempts have been made to combine both new product developers and the people who must face the customers and sell the new products. This dyad approach represents a second unique contribution to the NPD literature. 
Third, this research offers an alternative choice for the dependent variable. As will be discussed later, previous authors' measurement of success have generally focused on one product and often involved global measures of company success rather than the success of the firm's new product development program (e.g., Jaworski and Kohli, 1993). Success here is defined as new product program success rather than the success of a single product. Program success will be measured using five different metrics. This approach not only permits measurement of the new product program's success from different perspectives, but also provides evidence of one or more measures which is/are particularly robust. This research will then decompose the independent variable into its three sub-dimensions to test which, if any, most directly contributes to new product program success.

We will begin by reviewing pertinent literature relative to the theoretical development of the independent variable, IFMO, and the dependent variable, new product program success measures. Four hypotheses will be offered based on the literature review. A discussion of the measurement instrument and its derivation and subsequent testing will follow. The sampling procedure will explain the sampling frame and how information from the dyads was collected. Presentation of the findings will precede the final two sections, the discussion of the findings and the managerial implications.

\section{Market Orientation}

There has been considerable confusion in the literature on the proper terms for what eventually has become known as market orientation. Felton (1959, p. 55), in the Harvard Business Review, initially spoke of "integrated marketing." Payne (1988), in Business Horizons, used the term "marketing-oriented" and Piercy (1990), in the European Journal of Marketing, preferred the term "market-led." However, Shapiro (1988), in an attempt to fully explicate the meaning of market oriented, suggested that all these terms were so close that few important differences existed. Finally, Kohli and Jaworski (1990), in their seminal paper on market orientation, chose the term market orientation over marketing orientation. They did so for three reasons. First, the "market orientation" suggests that the behaviors and activities associated with a market orientation are not the exclusive domain of the marketing function, but rather all departments within the organization. Second, market orientation is less politicalsounding than marketing orientation and does not suggest a greater importance of the marketing function in the organization. Finally, the term focuses attention on the external factors of the market that include not only the customer, but also additional forces in the environment that affect the firm.

Market orientation is the organization-wide generation of market intelligence pertaining to current and future customer needs, dissemination of the intelligence across departments, and organization-wide responsiveness to it (Kohli and Jaworski, 1990, p. 6). Kohli and Jaworski (1990) suggested that a market orientation creates a collaborating focus in the management of the new product development process and this leads to superior company performance. Mavondo and Farrell (2000) suggest that Narver and Slater's (1990) definition of market orientation as an "organizational culture 
that effectively and efficiently creates behaviors..." elevates market orientation to the level of strategy, or strategic orientation. Deshpande and Farley (1998) further conceptualized market orientation, emphasizing its effect on the firm's behavioral processes at the functional level by defining market orientation as a set of "crossfunctional processes and activities directed at creating and satisfying customers by continuously assessing the needs of customers"(Hillebrand et al., 2001).

A central tenet of the market orientation construct is the need for virtually all departments, not just the marketing department, to participate in gathering, disseminating and responding to market intelligence (Kohli and Jaworski, 1990); "A market orientation appears to provide a unifying focus for the efforts and projects of individuals and departments within the organization, therefore leading to superior firm performance" (Kohli and Jaworski, 1990). Much of the academic research focusing on new product success emphasizes the need for effective communication among departments, particularly between $R$ \& $D$ (referred to here as the technology management group, a.k.a. "technology group") and marketing (e.g., Song and Parry, 1997; Norton et al., 1992).

Cross-functional new product teams have become the norm in many firms today (Smith and Reinertsen, 1991) and should, therefore, be a target for research investigating their impact on the firm's business performance. Previous research argues that the major participants of these teams are primarily technology and marketing personnel who appear to possess sufficiently differing cognitive perspectives to require treating them as separate populations (Maltz and Kohli, 2000; Griffin and Hauser, 1996: Dougherty, 1992).

Market orientation can be conceptualized below the strategic business level as interfunctional market orientation (IFMO). This designation permits the researcher to focus on the linkage between market orientation and new product program success. Interfunctional market orientation is quantified in this research as:

$$
\text { IFMO }=\mathrm{MO}_{1}+\mathrm{MO}_{2}-\left|\mathrm{MO}_{1}-\mathrm{MO}_{2}\right|
$$

where $\mathrm{MO}_{1}$ represents the level of market orientation of the marketing group within the new product development team and $\mathrm{MO}_{2}$ represents the level of market orientation of the technology group. The mathematical expression, $\left|\mathrm{MO}_{1}-\mathrm{MO}_{2}\right|$ reduces the market orientation level of a firm's new product team by an amount equal to the difference in their respective level of market orientation. It is conceptually a penalty score against market orientation; the greater the difference, no matter which direction, penalizes the sum $\mathrm{MO}_{1}+\mathrm{MO}_{2}$. The adjustment, therefore, is a logical response to current crossfunctional research, the findings of which suggest that new product teams must be in harmony to bring effective new products to the market efficiently (Lovelace et al., 2001; Maltz and Kohli, 2000; Jassawalla and Sashital, 1999).

Market orientation has been approached from two different basic perspectives provided by Kohli and Jaworski (1990) and Narver and Slater (1990). Kohli and Jaworski (1990) 
first characterized the domain of the market orientation construct and provided an operational definition and the conceptual framework for the development of a theory of market orientation. Three elements of market orientation emerged from their synthesis of field interviews with practitioners, business academics and literature reviewintelligence generation, dissemination, and responsiveness. Intelligence generation, pertains to the gathering of information related to customer needs, wants and preferences, both short- and long-term, and includes the monitoring and analysis of external factors impacting the firm. Kohli and Jaworski (1990) noted from their field interviews that intelligence dissemination is required in order for the entire firm to respond effectively to the market. In particular, $R$ \&D and marketing's participation were noted in the design, development and production of new products "because it provides a shared basis for concerted actions by different departments." Responsiveness to market intelligence includes the proper actions toward design, production, distribution and promoting products and services to the customer.

Kohli and Jaworski (1990) provide three additional points regarding their synthesis of the market orientation construct. First, they surmised that a market orientation should be viewed as a continuous rather than an either/or construct because organizations will differ in the level of activity and resources employed to gather market intelligence, disseminate market information internally, and ultimately respond to that information. They further suggest that the unit of market orientation analysis appears to be the strategic business unit, rather than the whole corporation, since different strategic business units are likely to represent different degrees of market orientation.

Narver and Slater's (1990) conceptualization of market orientation identified three behavioral components. First is a customer orientation that provides organizations with an understanding of the current and future needs of the buyer in order to create superior customer value. Second is a competitor orientation that provides organizations with an understanding of current and future competitor strengths, weaknesses and capabilities. Third is inter-functional coordination among the organization's departments.

\section{New Product Program Success}

In the literature, the process by which new products are developed is not always referred to as "new product development." Those in R \& D often refer to "innovation." Those in the engineering and design discipline may choose either "innovation" or "design." However, there appears to be no strict allegiance to the use of these terms by the particular domains. For the purpose of this research, the term "new product development" or "NPD" refers to the process of developing individual products and the firm's overall new product program.

Wind and Mahajan (1997) identified numerous issues critical for improving outcomes from the new product development process. In particular, they expressed concern with the specific issue of cross-functional integration. The nature of the interface and integration of marketing and $R \& D$ has been a research topic for over 20 years and continues as a rich area of academic research, including research investigating the link 
between market orientation and new product success (e.g., Kahn, 2001; Maltz and Kohli, 2000). The literature overwhelmingly supports the normative position that $R$ \& $D$ and marketing should be free of conflict. Craig and Hart (1992) emphasized the important role that information exchange plays in achieving inter-functional coordination and the way in which the information is communicated. Also, Pinto and Pinto (1990) further emphasized the connection between communication and functional coordination by suggesting that cross-functional communication was critical to the successful implementation of new product projects.

In addition, there are numerous issues regarding the use and choice of new product success measures. For example, there is considerable debate among firms about the frequency and presumed value of using new product performance measures (Craig and Hart, 1992). In fact, Cooper et al. (2004) recently suggested that only $30 \%$ of businesses measure new product performance on a regular and timely basis. However, Cooper notes that those firms with the most successful new product programs are three times more likely to use new product measures. A second issue is how to determine which combination of subjective and objective new product performance measures best elucidate new product success, at either the individual project level or overall new product development program. Subjective measures have been shown to correlate with objective measures (Dess and Robinson, 1984). A third issue is what measures are most appropriate for use by academicians and practitioners at the individual project level or when measuring the success of the firm's overall new product program (Griffin and Page, 1993).

A review of the new product research literature indicates that most studies have focused on the most recently developed or most recently launched new products. Individual project-level studies are predominant in research, focusing on time-to-market, new product stage development processes, product development cycle time, and development costs. However, academic researchers have conceded that often a single new product may not be representative of the firms' new product effort and that future research should consider multiple new products embedded in the firms' new product development program (e.g., Langerak et al., 2004). Recently, marketing and management researchers of new product performance have extended their analyses to include the firm's overall new product effort instead of a single project (Baker and Sinkula, 2002; Kahn, 2001). Much of the marketing, management and research technology literature suggest that many of the metrics for new product program success used by academic researchers are new measures specifically for measuring multiple product performance. Discussion of performance measures used to measure new product program success relating specifically to market orientation is discussed later in this section. Here, we next discuss the commonly used metrics used by $R \& D$ that specifically measure the firms' overall new product performance.

Time-to-market, R \& D intensity and the new sales ratio (NSR) are three primary measures most consistently identified in the research technology literature for tracking, monitoring and benchmarking a firm's overall new product program efforts (e.g., Bean et al., 2000; Whiteley et al., 1998). Time-to-market is generally associated with individual 
projects to benchmark the firm's ability to quickly develop, register and introduce new products into the market. $R \& D$ Intensity is a self-reported ratio of research expenditures to sales revenue and is generally a closely held metric. Unlike $R$ \& $D$ Intensity, NSR is often reported in company annual reports. The NSR directly reflects the firms' ability to produce future revenues from new products. It is, therefore, a useful measure for measuring the entire contribution of new products to the profitable growth of the firm (Whiteley et al., 1998). The NSR metric, while providing a snapshot of the firm's ratio of new product sales over total product sales, does not reflect the number of product candidates it took for the development team to get to the current NSR and its basket of successfully launched products. Cooper's early research (1983) and the survey findings from the Product Development Management Association indicated use and support for measuring the percent of sales by new products. Thus, there is considerable support for the NSR metric.

The first empirical study to examine the link between market orientation and new product success was by Slater and Narver (1994). Since then, there has been sporadic interest in the topic (e.g., Matsuno et al., 2002; Kahn, 2001; Subramanian and Gopalakrishna, 2001; Langerak, 2001; Baker and Sinkula, 1999; Appiah-Adu and Ranchhod, 1998). Most of these studies have shown a positive relationship between market orientation and new product success only at the individual project level and did not measure overall new product program success. Still fewer studies have investigated moderating effects to the market orientation-new product success relationship.

There is considerable variation in methodology, sample frames and measurements used in studies of new product success. Most market orientation studies have opted for a single-informant format, generally surveying non-technical managers such as senior marketing executives, managing directors, CEOs, presidents and owners. Although there is considerable support in the literature for using a single-informant format, academic researchers have begun to question this approach and have openly suggested that a bias exists in earlier marketing orientation studies, especially in investigating the link with business performance (Langerak et al., 2004; Kahn, 2001). Presumably, the bias occurs when only marketing or senior business executives are asked to provide input to academic research seeking to determine the firm's overall level of market orientation. This line of reasoning suggests there might be critical areas within the firm that are not market-oriented and not detected due to the choice of survey informant. For example, in a highly diverse cross-functional environment, such as NPD, a considerable degree of "disconnect" between marketing and technology personnel is most likely to exist (Aaby and Dicenza, 1993). The extent of this disconnect within NPD cross-functional groups may be unknown to top management and, therefore, not reflected in single-informant format surveys of senior marketing executives and CEOs, who are often removed from the day-to-day NPD process. Thus, this research utilizes the formula, IFMO $=M O_{1}+M O_{2}-\left|M O_{1}-M_{2}\right|$, to specifically measure the level of market orientation at the functional level.

A lack of effective communication between the marketing and the technology groups can be detrimental to the new product development process, leading to a poor fit 
between product characteristics and the needs of the customer (Schilling and Hill, 1998). In other words, the firm may be regarded as being highly market-oriented, but the new product development team may not be, and therefore superior business performance remains elusive. If this is the case, the lack of inter-functional market orientation (IFMO) could in part, explain the high failure rate for new products. The IFMO formula (IFMO $=M O_{1}+M_{2}-\left|M O_{1}-M_{2}\right|$ ) seeks to measure the market orientation level of these two independent, but collaborating departments in new product development.

Empirical research examining the market orientation-business performance link is equivocal (Subramanian and Golakrishna, 2001). Kahn (2001) points out that despite the continued importance of new products for driving firm performance (Schilling and Hill, 1998), there are few studies examining the link between market orientation and new product program performance; most focus on an individual product, not the NPD program (Langerak, 2001; Baker and Sinkula, 1999; Pelham and Wilson, 1996; Slater and Narver, 1994). The few studies empirically examining the relationship between market orientation and the firm's new product program performance underline a significant gap in the literature. Emphasizing this dilemma, the Marketing Science Institute identified new product success research as a first-tier priority for 2002-2004. Based on this literature and theoretical background it is hypothesized that:

$\mathrm{H}_{1}$ There is a positive relationship between an organization's level of IFMO and new product program success.

Following the Kohli and Jaworski (1990) conceptualization of market orientation (MO) where $\mathrm{MO}$ is the sum of intelligence gathering (IG), intelligence dissemination (ID) and response implementation $(\mathrm{RI})$, we would propose:

$\mathrm{H}_{2-1}$ The smaller the difference in the level of IFMO-computed market intelligence gathering between the marketing and technology management groups, the greater the firm's new product program success.

$\mathrm{H}_{2-2}$ The smaller the difference in the level of IFMO-computed information sharing between marketing and technology management groups, the greater the firm's new product program success.

$\mathrm{H}_{2-3}$ The smaller the difference in the level of IFMO-computed responsiveness between marketing and technology management groups, the greater the firm's new product program success.

\section{Market Orientation Measurement Constructs}

Following a review of the literature on existing market orientation scales and exploratory in-depth interviews of scale items with industry managers from the pharmaceutical industry, the Matsuno et al. (2000) "New MO" scale was judged to be the most applicable and appropriate for use in this study. The New MO scale is composed of 
three separate constructs: intelligence gathering (8-question scale), intelligence dissemination (6-question scale), and response implementation (8-question scale) following Kohli and Jaworski (1990). A reliability check of the New MO Scale and its individual constructs was performed using SPSS 12.0. For the 22-item New MO Scale, Cronbach's $\alpha=.88$. The $\alpha$-value for the intelligence gathering construct was $\alpha=.78$; for intelligence dissemination $\alpha=.77$; for response implementation $\alpha=.77$. These scores are well above the .70 level recommended by Nunnally (1978) and within the acceptable limits identified by Bearden, Netermeyer, and Mobley (1993). The scores compare favorably with Matsuno et al.'s (2000) reliability results where they reported Cronbach's alphas of .65 for intelligence gathering, .75 for intelligence dissemination, and .81 for response implementation and for the total 22-item New MO scale, $\alpha=.85$ (Matsuno et al., 2000). Table I reports the results of the reliability analysis for the marketing and technology groups' respondents

Table I

Multi-Item Scales and Reliability

\begin{tabular}{lcc}
\hline & \multicolumn{2}{c}{ Cronbach Alpha } \\
Scale & $\begin{array}{c}\text { Marketing } \\
\text { Group }\end{array}$ & $\begin{array}{c}\text { Technology } \\
\text { Group }\end{array}$ \\
\hline Marketing Orientation (22 Q's) & .876 & .891 \\
Intelligence Gathering (8 Q's) & .813 & .790 \\
Intelligence Dissemination (6 Q's) & .718 & .769 \\
Response Implementation (8 Q's) & .677 & .716 \\
\hline
\end{tabular}

\section{Measures of New Product Program Success}

Measuring new product success at the project and program level has been a growing research topic for over a decade (e.g., Griffin and Page, 1993). Of those earlier studies, there was a particularly important study performed by Cooper (1983) that identified nine performance measures used to measure new product success, with the most significant being a measure of the firm's overall new product program success." Cooper (1993) concedes that most new product success studies are perhaps too narrow in relying on a single performance measurement for individual products and that the result being a firm could be highly successful with the products it launches and have a strong overall new product program. Yet the new product program could have little positive impact on the firm's performance. In their final report of the PDMA Success Measurement Project, Griffin and Page (1996) recommended that no single measure would suffice for measuring the success of every new product development project.

For the research being reported here, one subjective measure and four objective measures were used to quantify the firm's new product program success. Subjective measures have been used in previous market orientation-new product success studies (Narver and Slater, 1994)) and have been found to strongly correlate with their objective counterparts (Pearce et al., 1987). The subjective measure asked respondents to rate their firm's overall new product program success relative to all other competitors in their 
industry (DV = RELCOMP). Respondents were asked, "Using a 7-point scale, rate your business unit's new product success rate, relative to all other competitors in your industry. For example, if you believe your business unit's success rate is greater than that of $60 \%$ of all competitors, rate yourself as a " 5 ". ( $1=<10 \% ; 2=11-25 \% ; 3=26$ $40 \% ; 4=41-55 \% ; 5=56-70 \% ; 6=71-85 \% ; 7=86-100 \%)$."

Four objective measures of new product program success were tested as dependent variables. The first of the objective measures was the New Sales Ratio (NSR). NSR, as used here, is the averaged value of the calculated NSR response from the respondent dyad from each participating company. The NSR metric is easily calculated, objective, auditable and a consistent measure across firms. There were five steps necessary for its calculation:

1. List all $R \& D$ projects that have been commercially introduced over the last 5 years.

2. Record the current year's sales for each new product.

3. Sum the sales recorded to determine the New Sales dollars for the year.

4. Divide the New Sales dollars by the current year's total sales to obtain the NSR as a ratio.

5. Multiply the ratio by 100 to express NSR as a percent.

The new sales ratio is useful for measuring the entire contribution of new products to the profitable growth of the firm (Whiteley et al., 1998). Cooper's research (1983) provided indirect support for the NSR. The NSR directly reflects the firm's ability to produce future revenues from new products and is used extensively by research firms. Collectively, the firm-based NSR, an industry-wide measure of the firm's new product success rate relative to competitors in same principal served market segments, provides a formidable measure of new product program success.

Three additional objective measures of new product program success identified how many successful new products the business unit had launched in the past year, three years and five years, respectively $\left(\mathrm{NP}_{12}, \mathrm{NP}_{36}\right.$ and $\left.\mathrm{NP}_{60}\right)$. The responses from the firm's marketing and technology groups to the $\mathrm{NP}_{12}, \mathrm{NP}_{36}$ and $\mathrm{NP}_{60}$ questions were averaged. The reasoning for the 1-, 3- and 5-year measures was that the product's life cycle may need to develop over several years before it reveals itself as being successful. A product that is deemed unsuccessful in the first year may simply be in the introduction stage of the life cycle where profits are negative and the product has not achieved significant traction. Introducing more than one product over several years would account for the program's success as measured not by one product alone, but by the array of products on the market for several years. Since the focus here is on program success rather than single product success, asking respondents about the program's success over several time frames seemed appropriate.

In testing the hypotheses for this research, each of these NPD success metrics was used as a separate DV in the hypothesis test and subsequent analysis. By taking this 
approach, both the hypothesized relationships get tested and the robustness or lack of robustness can be investigated for the NPD program success measures.

\section{The Sample}

The sample was drawn from a proprietary life science database of approximate 1,500 companies, containing manufacturing and service firms reportedly engaged in new product research and/or licensing of animal health/veterinary products to the veterinary profession in the US market. The database yielded a list of 125 firms currently engaged in veterinary NPD research. For this research, it was essential to have both a respondent from the company's marketing department and from the tech/R \& $D$ department for the IFMO calculation. Pre-testing the survey instrument was accomplished with six in-depth interviews and after editing, pre-testing the survey instrument on twelve different respondents.

Of the 125 firms surveyed, 51 firms met the criteria of a responding dyad (marketing respondent and tech respondent from the same company), for a total of 102 respondents submitting usable questionnaires (a response rate of $41 \%$ ). Data for the survey was obtained by a mailing or phone interview. Table II profiles the respondent pool.

Table II

Sample Respondent Characteristics

\begin{tabular}{llrr}
\hline Characteristic & \multicolumn{1}{c}{ Category } & $\mathbf{n}$ & $\mathbf{\%}$ \\
\hline Business Unit Revenues & < $10 \mathrm{M} \$$ & 10 & 19.6 \\
& $11 \mathrm{M} \$$ to $50 \mathrm{M} \$$ & 17 & 33.3 \\
& 50M\$ to 100M\$ & 5 & 9.8 \\
& $>100 \mathrm{M} \$$ & 19 & 37.3 \\
& & & \\
Functional Area & RandD/Technical & 41 & 40.2 \\
& Manufacturing/Engineering & 7 & 6.9 \\
& Marketing/B. Development & 39 & 38.2 \\
& President/CEO & 12 & 11.8 \\
\multirow{5}{*}{ Years in Current Position } & & \\
& Up to 5 Years & 41 & 40.2 \\
& 6 to 9 Years & 36 & 35.3 \\
& 10 to 15 years & 18 & 17.6 \\
& $>15$ years & 7 & 6.9 \\
Years with Company & Up to 5 Years & 29 & 28.4 \\
& 6 to 9 Years & 31 & 30.4 \\
& 10 to 15 Years & 27 & 26.5 \\
& $>15$ Years & 15 & 14.7 \\
\hline
\end{tabular}




\section{Findings}

Hypothesis $\mathrm{H}_{1}$ posited a positive relationship between an organization's level of interfunctional market orientation and new product program success. The results (Table III) showed there was a positive and significant relationship between an organization's inter-functional market orientation and new product program success for dependent variables RELCOMP $(\beta=.366, t=3.298 ; p<.001), N_{12}(\beta=.182, t=1.850 ; p<.10)$, $\mathrm{NP}_{36}(\beta=.185, \mathrm{t}=2.051 ; p<.05)$ and $\mathrm{NP}_{60}(\beta=.185, \mathrm{t}=1.879 ; p<.10)$. Therefore, hypothesis $\mathrm{H}_{1}$ is supported when measured by dependent variables RELCOMP, $\mathrm{NP}_{12}$, $\mathrm{NP}_{36}$ and $\mathrm{NP}_{60}$ but not when NSR is the dependent variable.

\section{Table III \\ Results for $\mathrm{H}_{1}$}

\begin{tabular}{lccccc}
\hline Model & \multicolumn{5}{c}{ Dependent Variables } \\
Summary & $\mathrm{NSR}$ & $\mathrm{NP}_{12}$ & $\mathrm{NP}_{36}$ & $\mathrm{NP}_{60}$ & $\mathrm{RELCOMP}$ \\
\hline Regression Coefficient & -.043 & .182 & .201 & .185 & .366 \\
T-test & -.429 & $1.850^{(3)}$ & $2.051^{(2)}$ & $1.879^{(3)}$ & $3.298^{(1)}$ \\
$\mathrm{R}^{2}$ & .002 & .033 & .040 & .024 & .134 \\
$\mathrm{~N}$ & 102 & 102 & 102 & 102 & 102 \\
\hline${ }^{(1)} \mathrm{p}<.001^{(2)} \mathrm{p}<0.05^{(3)} \mathrm{p}<0.10$ & & & & &
\end{tabular}

Hypothesis $\mathrm{H}_{2-1}$ posited that there is a positive relationship between an organization's level of IFMO in terms of only the intelligence gathering dimension and new product program success. The results (Table IV) do not support $\mathrm{H}_{2-1}$ for any of the five measures below the $p \leq .10$ level of significance.

\section{Table IV}

\section{Results for $\mathrm{H}_{2-1}$}

\begin{tabular}{lrrrrr}
\hline Model & \multicolumn{4}{c}{ Dependent Variables } \\
Summary & $\mathrm{NSR}$ & $\mathrm{NP}_{12}$ & $\mathrm{NP}_{36}$ & $\mathrm{NP}_{60}$ & \multicolumn{1}{c}{$\mathrm{RELCOMP}$} \\
\hline Regression Coefficient & .087 & -.141 & -.123 & -.110 & -.176 \\
T-test & .871 & -1.426 & -1.235 & -1.104 & -1.792 \\
$\mathrm{R}^{2}$ & .008 & .020 & .015 & .012 & .031 \\
$\mathrm{~N}$ & 102 & 102 & 102 & 102 & 102 \\
\hline
\end{tabular}

${ }^{1}$ No Significance on any DV

Hypothesis $\mathrm{H}_{2-2}$ posited that there is a positive relationship between an organization's level of IFMO in terms of only the information sharing dimension and new product program success. The results (Table $\mathrm{V}$ ) showed that the hypothesized relationship is positive and significant for the dependent variable NSR $(\beta=.291, t=3.044 ; p<.01)$. Therefore, hypothesis $\mathrm{H}_{2-2}$ is supported when measured by only the dependent variable NSR. 


\section{Table V \\ Results for $\mathrm{H}_{2-2}$}

\begin{tabular}{lccccc}
\hline Model & \multicolumn{5}{c}{ Dependent Variables } \\
Summary & $\mathrm{NSR}$ & $\mathrm{NP}_{12}$ & $\mathrm{NP}_{36}$ & $\mathrm{NP}_{60}$ & $\mathrm{RELCOMP}$ \\
\hline Regression Coefficient & .291 & -.027 & -.054 & -.113 & .069 \\
T-test & $3.044^{(1)}$ & -.270 & -.538 & -1.113 & .690 \\
$\mathrm{R}^{2}$ & .085 & .001 & .003 & .013 & .005 \\
$\mathrm{~N}$ & 102 & 102 & 102 & 102 & 102 \\
\hline
\end{tabular}

(1) $p<.01$

Hypothesis $\mathrm{H}_{2-3}$ posited that there is a positive relationship between an organization's level of IFMO in terms of only the response dimension and new product program success. The results (Table VI) showed that there is a positive and significant relationship between an organization's level of IFMO in terms of the response dimension and new product program success for dependent variable NSR $(\beta=.197, \mathrm{t}=$ 2.006; $p<.05$ ). Therefore, hypothesis $\mathrm{H}_{2-3}$ is supported when measured by only the dependent variable NSR.

Table VI

Results for $\mathrm{H}_{2-3}$

\begin{tabular}{|l|c|c|r|r|c|}
\hline Model & \multicolumn{5}{|c|}{ Dependent Variables } \\
\hline Summary & $\mathrm{NSR}$ & $\mathrm{NP}_{12}$ & $\mathrm{NP}_{36}$ & $\mathrm{NP}$ & $\mathrm{R} 0$ \\
\hline Regression Coefficient & .197 & -.239 & -.176 & -.227 & -.066 \\
\hline T-test & $2.006^{(1)}$ & -2.456 & -1.786 & -2.328 & -.661 \\
\hline $\mathrm{R}^{2}$ & .039 & .057 & .031 & .051 & .044 \\
\hline $\mathrm{N}$ & 102 & 102 & 102 & 102 & 102 \\
\hline
\end{tabular}

(1) $p<.05$

\section{Conclusions}

The results of this research show that overall inter-functional market orientation as measured by IFMO via the New MO scale, has a positive and significant impact on new product program success. Table VII summarizes the results. 


\section{Table VII \\ Results of Hypotheses Testing}

\begin{tabular}{|l|l|}
\hline $\begin{array}{l}\mathrm{H}_{1} \text { There is a positive relationship between an organization's } \\
\text { degree of inter-functional market orientation and new product } \\
\text { program success. }\end{array}$ & $\begin{array}{l}\text { Significant: } \\
\text { RELCOMP, } \\
\text { NP12, NP36 } \\
\text { AND NP60 }\end{array}$ \\
\hline $\begin{array}{l}\mathrm{H}_{2-1} \text { The smaller the difference in the level of IFMO-computed } \\
\text { market intelligence gathering between the marketing and } \\
\text { technology management groups, the greater the firm's new } \\
\text { product program success. }\end{array}$ & Not Supported \\
\hline $\begin{array}{l}\mathrm{H}_{2-2} \text { The smaller the difference in the level of IFMO-computed } \\
\text { information sharing between marketing and technology } \\
\text { management groups, the greater the firm's new product } \\
\text { program success. }\end{array}$ & Significant: NSR \\
\hline $\begin{array}{l}\mathrm{H}_{2-3} \text { The smaller the difference in the level of IFMO-computed } \\
\text { responsiveness between marketing and technology } \\
\text { management groups, the greater the firm's new product } \\
\text { program success. }\end{array}$ & Significant: NSR \\
\hline
\end{tabular}

The findings from this research provide for several conclusions regarding the role and impact of a market orientation on the firm's new product efforts. A major conclusion from this research is that past research designs for measuring the impact of market orientation on a firm's new product efforts may be flawed. The results from past market orientation-business performance studies when contrasted with market orientation-new product success studies suggest possible methodological issues. For example, early market orientation studies have generally shown a positive link with overall business performance by various measures, such as return on assets (Narver and Slater, 1990), return on investment (Gray et al., 1998), sales growth (Ruekert, 1992), market share growth, and overall performance (Jaworski and Kohli, 1993). Positive links have also been found in different contexts, such as hospitals (Naidu and Narayana, 1991), product manufacturing (Wren et al, 2000) and smaller firms (Pelham and Wilson, 1996). The empirical evidence of the impact a market orientation has on new product success has generally been mixed and puzzling. A positive link between market orientation and new product success was shown by Subramanian and Gopalakrishna (2001), Baker and Sinkula (1999), Slater and Narver (1994). However, no effect, or negative results, for the market orientation-new product success link have been reported in several empirical studies including Kahn (2001) and Greenley (1995). Therefore, based upon evidence cited in the literature, this research methodologically approached the market orientationnew product success link differently. First, unlike most market orientation-new product studies respondents for this investigation were chosen for their intimate familiarity with cross-functional new products behavior. Second, the survey instrument was administered to two respondents whose responses were combined to reduce bias (Huber and Power, 1985). Third, one respondent each from business development and technology management with intimate knowledge of the firm's new product strategy were surveyed. Fourth, this investigation responded to calls in the literature to include 
the results of more than one product in new product success studies. Thus, a firm's overall new product program success was evaluated. Fifth, new product program success measures that were previously used in market orientation and new product development studies were used. The validated market orientation scale (Matsuno et al., 2000) was administered below the SBU level at the functional level and to crossfunctional teams. Conceptually, the market orientation measured is an inter-functional measure within the organization and thus called inter-functional market orientation to distinguish the measure from previous SBU-level market orientation studies.

The results of this research provide strong evidence of a positive link between interfunctional market orientation and overall new product program success. Hypothesis 1 posited that there is a positive relationship between an organization's degree of interfunctional market orientation and new product program success. This hypothesis was fully supported when measured by RELCOMP, NP ${ }_{12}, \mathrm{NP}_{36}, \mathrm{NP}_{60}$. The conclusive evidence reflects expectations of academics in the product development literature. Several studies have indicated that market orientation is a driver of product development performance (e.g., Li and Calantone, 1998; Montoya-Weiss and Calantone, 1994). Intuitively, successful new product development is about understanding the needs and wants of the customer very early in the product development process to assure a proper and attractive product-to-market fit.

The product development literature is replete with theory, conceptual models and empirical studies investigating the relationship between functional groups within product development teams. Since R \& D and marketing are most frequently involved in the new product development process from idea to commercialization, much of the literature addresses the impact of inter-group conflict and integrating activities on new product development processes and success (e.g., Griffin and Hauser, 1996). The importance of integrating $R \& D$ and marketing activities on new product development and the numerous studies indicating the positive role of a market orientation in fostering new product success (e.g., Li and Calantone, 1998), provided the impetus to investigate the linkage between IFMO-computed components of market orientation-market intelligence, information dissemination and response implementation-on new product program success.

Hypothesis 2-1 posited that the smaller the difference in the level of IFMO-computed market intelligence gathering between the marketing and technology management groups, the greater the firm's new product program success. Hypothesis 2-1 was not supported.

Hypotheses 2-2 posited that the smaller the difference in the level of IFMO-computed information sharing between marketing and technology management groups, the greater the firm's new product program success. Hypothesis 2-2 was supported when measured by NSR, $p<0.01$.

Hypothesis 2-3 posited that the smaller the difference in the level of IFMO-computed responsiveness between marketing and technology management groups, the greater 
the firm's new product program success. Hypothesis 2-3 was supported when measured by NSR, $p<0.05$.

Marketing and technology managers gather different market intelligence. Marketing managers generally gather information specifically related to the customer, such as wants and needs, and in particular marketing mix details such as pricing, distribution, promotion. On the other hand, technology managers are more concerned with technical issues, such as performance, efficacy, safety, design and manufacturing processes, and therefore are more likely to be gathering data regarding them. Also, technology managers might interpret market intelligence as customer information only that is best gathered and interpreted by marketing managers. No support for Hypothesis 2-1 seems counter-intuitive. However, it can be argued that little difference in the amount of market intelligence gathering between marketing and technology managers reflects the absence of a leadership role of the two. In a technology-driven organization, the technology management group would presumably play a strong to dominant role in market intelligence gathering and the culture in the new product development environment. In a market-driven organization, the marketing group would presumably reflect a contrasting role by the two management groups with marketing dominating the market intelligence gathering tasks.

Although marketing and technology managers do gather different information in order to complete their product development tasks, consistent dissemination of gathered information between the two groups, proper and timely group responsiveness would most logically contribute to new product program success. It is also logical to assume that small, perceived differences would contribute to less interdepartmental conflict, greater cooperation and harmony between the two management groups. Therefore, it is concluded that the smaller the difference in the level of IFMO-computed information dissemination and responsiveness between marketing and technology management groups, the greater the firm's new product program success.

\section{Managerial Implications}

The managerial implication is that new products have a greater chance of success when the key players, marketing and technical in this case, are sharing the same information and are comparably responding to that information. There are several important implications of this research for strategic and functional managers.

First, the need for managing information flows and diminishing conflict between $R$ \& $D$ and marketing has been recognized since the 1970's (Rubenstein et al., 1976). It remains a problem today and continues to be the subject of an important literature stream in product management (e.g., Hillebrand and Biemans, 2004).

Second, this research has shown that the more similar the market orientation level between the technology and marketing groups and the higher the level of intelligence dissemination (a component of a market orientation) between the technology and marketing groups, the greater the firm's new product program success. Therefore, it is not unreasonable to assume that similar levels of market orientation shared by these 
two groups might serve to enhance information flow and diminish interdepartmental conflict. Thus, the implication for management is that fostering a market orientation in cross-functional new product teams not only improves new product program success, but also enhances information flow and reduces interdepartmental conflict. This research is very encouraging to practitioners because it provides additional empirical evidence of the value of building and maintaining a market orientation throughout the firm. In particular, the results of this research provide evidence that the inter-functional market orientation level of the firm's new product team can be expected to positively improve business performance by achieving greater new product program success.

Third, additional measures of new product program success used in this research should be valuable to new product managers. Traditionally, firms have more often measured the success and failure rates of individual products rather than the performance of their new product output over time. However, there is considerable interest in utilizing more aggregate new product data (Griffin and Page, 1993). The research management and project management literature identified the new sales ratio, NSR, as the primary measure for new product program success. Additional measures used by firms to measure the firm's new product program success included the number of new products launched in the last 12, 36, and 60 months, respectively, and success relative to competition (RELCOMP) and they were found to be significant in one of the four hypotheses. This suggests that they hold promise as possible additional measures to be used in conjunction with NSR. This also suggests that previous research using only NSR as the success metric may have discovered additional or alternative results had such measures as these been included.

This paper posed two questions. First, what is the relationship between inter-functional market orientation and new product program performance? Second, is NSR the measurement variable of choice, as the literature suggested? The findings presented here would seem to indicate support for these questions.

These results suggest new product development programs would be more successful if the technical department and the marketing department were in harmony with respect to each one's ability or desire to gather, disseminate and respond to market intelligence. Furthermore, it behooves new product development managers to make sure that all inter-functioning departments are receiving, sharing and disseminating similar information. Success in creating and marketing new products can be improved if marketing and technical departments are literally and figuratively on the same page.

\section{$\underline{\text { Limitations }}$}

There are several limitations to this study. First, the finding in this research must be viewed as tentative, since there is very little empirical research investigating the relationship of market orientation and new product program success.

Second, the context of this study effectively limits any broad generalization of its findings beyond the animal health and veterinary products industry. Furthermore, the 
sampling frame was limited to the U.S. market and only to firms and SBUs that had research dedicated to the development of products for the licensed, practicing veterinarian.

Another limitation is the "snapshot" nature of the information received from the respondents. Most of the firms in this study have numerous products in various phases of development. Replication of this study several months before or after the initial data collection could, most likely, reflect major new product offerings and could impact the inter-functional market orientation-new product program success relationship.

Fourth, the animal health industry has undergone an extensive contraction in the number of $100 \mathrm{M} \$$ revenue firms in the past five years. At the same time, numerous start-ups, often with only a few products have emerged. Therefore, the landscape is dotted with new firms, some that were parts of larger firms, some new-to-the-industry firms, and some with limited research capabilities but major revenue-generating features. The result is an industry where many firms have little new product program history.

\section{Future Research Directions}

The findings in this research precipitate numerous questions and illuminate several areas of research that need to be explored. First, since inter-functional market orientation is a new construct introduced in this research, replication studies should be advanced to gain a greater understanding of the relationship between inter-functional market orientation and new product program success. Also, additional replication should consider longitudinal studies, since causal inferences cannot be made for within-firm effects with the performance measures.

A major area of research should examine the impact of inter-functional market orientation on other aspects of new product development. This is an entirely new and rich area of research for the inter-functional market orientation construct. Numerous studies continue to emphasize the sharing of market information, connectivity and coordination between marketing and $R \& D$, the primary new product team members. Numerous research questions arise. For example, what is the role of inter-functional market orientation on the quality of new product planning and its role in idea generation? Also, within the various new product stages of development how does the level of inter-functional market orientation impact the success/failure rates of product candidates as they proceed towards commercialization? Does the level of interfunctional market orientation reduce the level of conflict between marketing, $R \& D$ and other functional areas associated with the firm's new product effort? Do minimum differences in the sub measures of inter-functional market orientation levels between marketing and technology groups promote greater integration and foster superior new product development efficiencies, such as improved levels of research intensity? These questions are of considerable interest to top management who seek answers and remedies to poor performing research programs. 
Replication of the inter-functional market orientation-new product program success relationship should be extended to additional contexts and industries, such as, the human health sectors, biotechnology and other high technology industries that depend upon a continuous stream of new products for growth and survival. The service sector is a growing area of research for market orientation. Research should consider the impact of inter-functional marketing orientation in the banking, insurance and other service sectors of the economy.

There are numerous avenues of research for investigating the impact of inter-functional marketing orientation on the firm performance. For example, how does a firm develop an inter-functional market orientation? What is the relationship between the firm's level of market orientation and independently measured cross-functional market orientation? Are both market orientation and inter-functional market orientation necessary for optimizing overall business performance and sustaining competitive advantage?

The survey instrument used in this study may require further refinement. Several academic researchers call for the use of different scales in similar contexts towards validation of their ability to reflect the domain of the market orientation construct. Interfunctional marketing orientation will require further explication.

This research suggests new streams of literature toward the development of a theory of market orientation. Earlier academic research provided the framework and understanding of the dynamics of organizational market orientation and its impact on overall firm performance. Future market orientation research should clearly examine its impact on firm and departmental performance, especially considering the importance of a steady stream of new products, continued emergence of new business models and the strategic importance of the Internet for obtaining a competitive advantage.

\section{References}

Aaby, N. E. \& Discenza, R. (1993). Strategic Marketing and New Product Development. Journal of Business and Industrial Marketing, 8(2), 61-69.

Appiah-Adu, K. \& Ranchhod, A. (1998). Market Orientation and Performance in the Biotechnology Industry: An Exploratory Empirical Analysis. Technology Analysis and Management, 10(2), 197-210.

Baker, W. \& Sinkula, J.M. (1999). Learning Orientation, Market Orientation, and Innovation: Integrating and Extending Models of Organizational Performance. Journal of Market-Focused Management, 4(4), 295-308.

Baker, W. \& Sinkula, J. M. (2002). Market Orientation, Learning Orientation and Product Innovation: Delving into the Organization's Black Box. Journal of Market-Focused Management, 5(1), 5-23. 
Bean, A., Russo, M. J. \& Whiteley, R. L. (2000). Benchmarking Your R \& D Results from IRI/CIMS Annual R \& D Survey for FY '98. Research Technology Management, $\underline{43}(1), 16-24$.

Beardon, W. O., Netermeyer, R. G. \& Mobley, M. F. (1993). Handbook of Marketing Scales. Newbury Park: Sage.

Clancy, K. \& Shulman, R. (1991). The Marketing Revolution: A Radical Manifesto for Dominating the Marketplace. New York: Harper Business.

Cooper, R., Eggert, S. \& Kleinschmidt, E. (2004). Benchmarking Best Practices-III. Research Technology Management, 47(6), 43-55.

Cooper, R. (1983). The Impact of New Product Strategies. Industrial Marketing Management, 12(4), 243-257.

Cooper, R. G. (1993). Winning at New Products: Accelerating the Process from Idea to Launch. Reading, MA: Addison-Wesley.

Craig, A. \& Hart, S. (1992). Where to Now in New Product Development Research? European Journal of Marketing, 26(11), 1-49.

Crawford, M. (1977, April). Marketing Research and the New Product Failure Rate. Journal of Marketing, 41, 51-56.

Deshpande, R. \& Farley, J. (1998). Measuring Market Orientation: Generalizations and Synthesis. Journal of Market-Focused Management, 2(3), 213-232.

Dess, G. G. \& Robinson, R. B. (1984, July-September). Measuring Organizational Performance in the Absence of Objective Measures: The Case of Privately Held Firms and Conglomerate Business Units. Strategic Management Journal, 5, 265-273.

Dougherty, D. (1992). Interpretive Barriers to Successful Product Innovation in Large Firms. Organizational Science, 3(3), 179-202.

Felton, A. P. (1959). Making the Marketing Concept Work. Harvard Business Review, 37(4), 55-65.

Gray, B., Matear, S., Boshoff, C. \& Matheson, P. (1998), Developing a Better Measure of Market Orientation, European Journal of Marketing, 32(10), 884-903.

Greenley, G. (1995). Market Orientation and Company Performance: Empirical Evidence from U.K. Companies. British Journal of Management, 6(1), 1-13.

Griffin, A. \& Page, A. L. (1993). An Interim Report on Measuring Product Development Success and Failure. Journal of Product Innovation Management, 10(4), 291-308. 
Griffin, A. \& Page, A. L. (1996). PDMA Success Measurement Project: Recommended Measures for Product Development Success and Failure. The Journal of Product Innovation and Management, 13(6), 478-496.

Griffin, A. \& Hauser, J. R. (1996). Integrating R \& D and Marketing: A Review and Analysis of the Literature. Journal of Product Innovation Management, 13(3), 191-215.

Hillebrand, B., Kok, R. \& Biemans, W. (2001). Theory-testing Using Case Studies: A Comment on Johnston, Leach and Liu. Industrial Marketing Management, 30(8), 651.

Hillebrand, B. \& Biemans, W. G. (2004). Links Between Internal and External Cooperation in Product Development: An Exploratory Study. Journal of Product Innovation Management, 21(2), 110-122.

Huber, G. \& Power, D. (1985). Retrospective Reports of Strategic-level Managers: Guidelines for Increasing their Accuracy. Strategic Management Journal, 6(2), 171-181.

Jassawalla, A. R. \& Sashittal, H. C. (1999). Building Collaborative Cross-functional New Product Teams. The Academy of Management Executive, 13(3), 50-63.

Jaworski, B. J. \& Kohli, A.K. (1993). Market Orientation: Antecedents and Consequences. Journal of Marketing, 57(3), 53-70.

Kahn, K. (2001). Market Orientation, Interdepartmental Integration, and Product Development Performance. Journal of Product Innovation Management, 18(5), 314-323.

Kohli, A. K. \& Jaworski, B. J. (1990). Market Orientation: The Construct, Research Propositions, and Managerial Implications. Journal of Marketing, 54(2), 1-18.

Langerak, F., (2001). The Relationship Between Customer and Supplier Perceptions of the Manufacturer's Market Orientation and its Business Performance. International Journal of Market Research, 43(1), 43-62.

Langerak, F., Hultink, E. \& Robben, H. S. J. (2004). The Impact of Market Orientation, Product Advantage, and Launch Proficiency on New Product Performance and Organizational Performance. Journal of Product Innovation Management, 21(2), 79-84.

Li, T. \& Calantone R. J. (1998). The Impact of Market Knowledge Competence on New Product Advantage: Conceptual and Empirical Examination. Journal of Marketing. 62(4), 13-29.

Lovelace, K., Shapiro, D. L. \& Weingart, L. R. (2001). Maximizing Cross-functional New Product Teams' Innovativeness and Constraint Adherence: A Conflict Communications Perspective. Academy of Management Journal, 22(4), 779-793. 
Maltz, E. \& Kohli, A. (1996). Market Intelligence Dissemination Across Functional Boundaries. Journal of Marketing Research, 33(2), 47-61.

Maltz, E. \& Kohli, A. (2000). Reducing Marketing's Conflict with Other Functions: The Differential Effects of Integrating Mechanisms. Academy of Marketing Science Journal, $\underline{28}(4), 479-492$.

Matsuno, K., Mentzer, J. T. \& Rentz, J. O. (2000). A Refinement and Validation of the Markor Scale. Journal of the Academy of Marketing Science, 28(4), 527-539.

Matsuno, K., Mentzer, J. T. \& Ozsomer, A. (2002). The Effects of Entrepreneurial Proclivity and Market Orientation on Business Performance. Journal of Marketing, 66(7), 18-32.

Mavondo, F. \& Farrell, M. (2000). Measuring Market Orientation: Are There Differences Between Business Marketers and Consumer Marketers? Australian Journal of Management, 25(2), 223-244.

Montoya-Weiss, M. M. \& Calantone, R. G. (1994). Determinants of New Product Performance: A Review and Meta-analysis. Journal of Product Innovation Management, 11(5), 397-417.

Naidu, G. M. \& Narayana, C. L. (1991). How Marketing Oriented are Hospitals in a Declining Market? Journal of Health Care Marketing, 11(1), 23-30.

Narver, J. C. \& Slater, S. (1990). The Effect of Market Orientation on Business Profitability. Journal of Marketing, 54(10), 20-35.

Nunnally, J. (1978). Psychometric Theory $\left(2^{\text {nd }}\right.$ ed.) New York: McGraw-Hill.

Ottum, B. D. \& Moore, W. L. (1997). The Role of Market Information in New Product Success/Failure. Journal of Product Innovation Management, 14(4), 258-273.

Payne, A. (1988, May/June). Developing a Marketing-oriented Organization. Business Horizons, 31(3), 46-53.

Pearce, J. A., II, Robbins, D. K. \& Robinson, R. B., Jr. (1987). The Impact of Grand Strategy and Planning Formality on Financial Performance. Strategic Management Journal, 8(2), 125-135.

Pelham, A. \& Wilson, D. (1996). A Longitudinal Study of the Impact of Market Structure, Firm Structure, Strategy, and Market Orientation Culture on Dimensions of Small Firm Performance. Journal of the Academy of Marketing Science, 24(1), 27-43.

Piercy, N. (1990). Marketing Concepts and Actions: Implementing Marketing-led Strategic Change. European Journal of Marketing, 24(2), 32-51. 
Pinto, M. B. \& Pinto, J. K. (1990). Project Team Communication and Cross-functional Cooperation in New Program Development. Journal of Product Innovation Management, 7(3), 200-212.

Rubenstein, A. H., Chakrabarti, A., K., O'Keefe, R. D., Souder, W. E. \& Young, H. C. (1976). Factors Influencing Innovation Success at the Project Level. Research Management, 19(3), 15-20.

Ruekert, R. W. (1992). Developing a Market Orientation: Organizational Perspective. International Journal of Research in Marketing, 9(3), 225-245.

Schilling, M. \& Hill, C. W. H. (1998). Managing the New Product Development Process: Strategic Imperatives. Academy of Management Executive, 12(3), 67-81.

Shapiro, B. (1988, November/December). What the Hell is Market Oriented? Harvard Business Review, 66, 119-125.

Slater, S. \& Narver, J.C. (1994). Does the Competitive Environment Moderate the Market Orientation-performance Relationship? Journal of Marketing, 58(1), 46-55.

Slater, S. \& Narver, J.C. (1994, Mar/April). Market Orientation, Customer Value and Superior Performance. Business Horizons, 37(2), 22-28.

Smith, P. G. \& Reinertsen, D. G. (1991). Developing Products in Half the Time. New York: Van Nostrand Reinhold.

Song, M., Parry, W. \& Mark, E. (1997). The Determinants of Japanese New Product Success. Journal of Marketing Research, 34(1), 64-76.

Subramamian, R. \& Gopalakrishna, P. (2001). The Market Orientation - Performance Relationship in the Context of a Developing Economy. Journal of Business Research, $\underline{53}(1), 1-13$.

Whiteley, R., Patish, T., Dressler, R. \& Nicholson, G. (1998). Evaluating R \& D Performance Using the New Sales Ratio. Research Technology Management, 41(5), 20-22.

Wind, J. \& Mahajan, V. (1997). Issues and Opportunities in New Product Development: An Introduction to the Special Issue. Journal of Marketing Research, 34(2), 1-12.

Wren, B., Souder, Berkowitz, W. \& Berkowitz D. (2000), Market Orientation and New Product Development in Global Industrial Firms. Industrial Marketing Management, $\underline{29}(6), 601-611$. 